\title{
Ceropegia wallichii Wight (Apocynaceae Juss.): A New Elevation Record with Conservation Status
}

Ishwar Prakash Sharma ( $\square$ ipsharma.com@gmail.com )

Patanjali Research Institute https://orcid.org/0000-0001-8920-3100

\section{Short Report}

Keywords: Ceropegia wallichii, Elevation, Conservation, Threat

Posted Date: February 9th, 2022

DOI: https://doi.org/10.21203/rs.3.rs-1333751/v2

License: (9) This work is licensed under a Creative Commons Attribution 4.0 International License. Read Full License 


\section{Abstract}

The genus Ceropegia L. is a highly diversified genus of the family Apocynaceae whose most of the species are facing threats. The species Ceropegia wallichii Wight is categorized under Data Deficient (DD) which is found between 2500 to $2900 \mathrm{~m}$ altitudes since till date according to available literature while this article first time mentioned its elevation in $1735 \mathrm{~m}$ altitude. Hence, in this scenario, its new elevation should be changed from 1700 to $2900 \mathrm{~m}$. Owing to its poor abundance of sheets in Indian herbaria, this species also needs to be protected.

\section{Full Text}

The genus Ceropegia L. belongs from the Apocynaceae family of flowering plants that comprises 244 species mainly distributed in Africa and Madagascar, from where it extended to Arabia, India, China, the northern part of Australia, and the Canary Islands (Bruyns 2014; Singh 2015a,b; Singh and Garg 2015) This genus is highly diversified with the highest diversity in South Africa, Kenya, Madagascar, and India (Murthy et al. 2012). In old literature by Ahmedullah and Nayar (1987) in India, the genus represented by 53 species, 2 subspecies and 6 varieties of which 37 are endemic to Peninsular India, by Murthy et al. (2012) 55 species with 4 varieties, of which nearly 43 species are facing threats, by Karthikeyan et al. (2009) and Singh (2015b) 60 species, 2 subspecies, and 5 varieties are represented; while recently in a revision by Kambale and Yadav (2019) this genus has 61 taxa under 7 sections. Among all the species Ceropegia wallichii Wight is a quite robust looking species that grows upright and reaches a height of about $13-40 \mathrm{~cm}$ with spindle-shaped fleshy roots and slightly downy hairy strong shoot having left only in the upper area that occurs in altitudes from 2500 to 2900 m in open terrain (Marten 1919; Ansari 1984; Albers and Meve 2002) while I found this plant first time in altitude of $1735 \mathrm{~m}$ (Fig. 1) at the locality of Manila at district Almora in Kumaun region of Uttarakhand; the plant images captured which were grown in a pine forest (Fig. 2). The plant recorded regularly during its growth each year in that region. Hence, now the elevation of this species should be changed from 1700 to $2900 \mathrm{~m}$.

Taxonomically the species Ceropegia wallichii Wight belongs to the genus Ceropegia L., ser. Wallichianae $\mathrm{H}$. Huber of section Chionopegia H. Huber from the family Apocynaceae (Kambale and Yadav 2019). It is a perennial erect herb with a 13-40 cm long stem, rootstock with a fascicle of tuberous roots. The leaves are subsessile to shortly petiolated only in the upper part of the stem, lamina ovate-elliptic-lanceolate, acute-acuminate at apex, narrow at the base. Flowers solitary, extra-axillary, sepals pubescent, corolla tube long with gradually dilated towards the base, funnel-shaped at the throat, hairy within, lobes connate at the tip forming ovoid-cage, densely hairy, corona bi-seriate, outer five with bifid lobes, ciliate along margins; inner five erect with linear lobes. Follicles long, glabrous, seeds ovate, marginate, brown, silky white (Kambale and Yadav 2019).

Due to the presence of few sheets at Indian herbaria of the Ceropegia wallichii, it has been categorized under Data Deficient (DD) (Kambale and Yadav 2019) while in the study of Murthy et al. (2012) it was considered under rare and endemic. Similarly, in my observation site, I found a single plant every year at 
the locality. In this scenario, this plant needs to be conserved. It can be conserved ex-situ by seeds propagating in similar ecological habitats or botanical gardens. Micropropagation is a recent advanced in-situ conservation method using tissue culture that could be explored for mass multiplication and reintroduction into its natural habitats. Due to the very rare presence of this, harvesting plant or plant parts from natural habitats must be strictly prohibited. Along with these, we need to understand its reproductive biology, genetic architecture, evolutionary relationship, etc. for their re-establishment in nature.

\section{Declarations}

\section{Acknowledgment}

The authors are thankful to all researchers whose results are included in the present article.

\section{Competing interests}

The authors declare no competing interests.

\section{References}

Ahmedullah, M. \& M.P. Nayar (1987). Endemic Plants of the Indian Regions. Botanical Survey of India, Kolkata.

Albers, F. \& U. Meve (2002). Illustrated Handbook of Succulent Plants: Asclepiadaceae. Springer.

Ansari, M.Y. (1984). Asclepiadaceae: Genus Ceropegia. In: Flora of India. Botanical Survey of India Calcutta 16: 1-34.

Bruyns, P.V. (2014). The Apocynaceae of Namibia. Strelitzia. South African National Biodiversity Institute, Pretoria, pp 1-158.

Kambale, S.S. \& S.R. Yadav (2019). Taxonomic revision of Ceropegia (Apocynaceae: Ceropegieae) in India. Rheedea 29(1): 1-115.

Karthikeyan, S., M. Sanjappa \& S. Moorthy (2009). Flowering Plants of India: Dicotyledons (Acanthaceae-Avicenniaceae), vol. 1. Botanical Survey of India, Kolkata, pp 160-164.

Marten, J. (1919). A few Additions to the List of Mussoorie Plants in Vol. XIX. Journal of the Bombay Natural History Society 26(2): 695-696.

Murthy, K.S.R., R. Kondamudi, M.C. Reddy, S. Karuppusamy \& T. Pullaiah (2012). Checklist and conservation strategies of the genus Ceropegia in India. International Journal of Biodiversity and Conservation 4(8): 304-305. 
Singh, R.K. \& A. Garg (2015). Lectotypifications of two names of Indian species of Ceropegia (Apocynaceae). Telopea 18: 305-308.

Singh, R.K. (2015a). Lectotypification of two names of Indian species of Ceropegia (Apocynaceae). Telopea 18: 305-308.

Singh, R.K. (2015b). Lectotypifications of some Indian Ceropegia (Apocynaceae: Ceropegieae). Phytotaxa 197(2): 157-160.

\section{Figures}

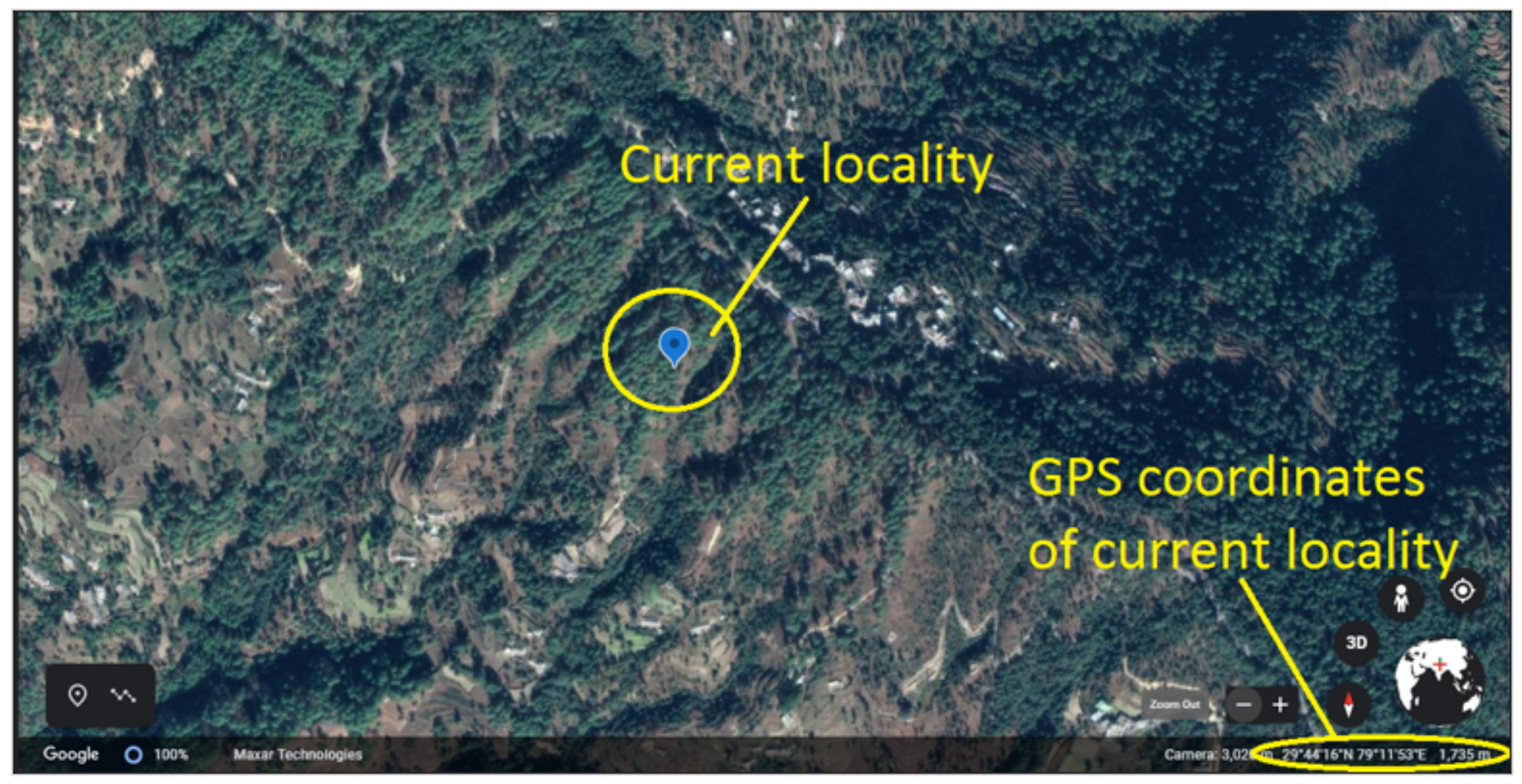

\section{Figure 1}

Locality of Ceropegia wallichii at altitude of $1735 \mathrm{~m}$ in Google earth location 


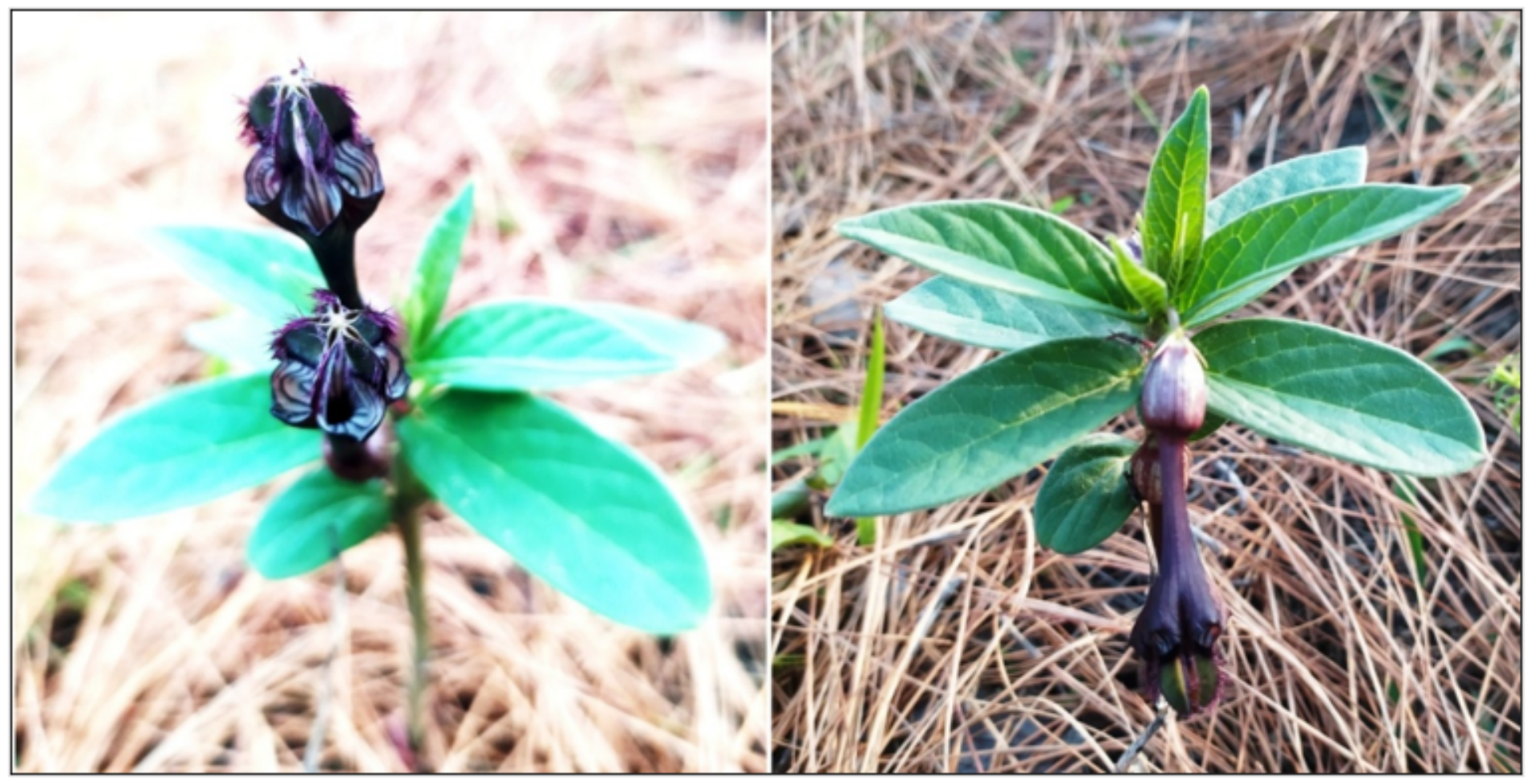

Figure 2

Natural habitat of Ceropegia wallichii in present locality 